\title{
USE OF GENETICALLY MODIFIED MUSCLE AND FAT GRAFTS TO REPAIR DEFECTS IN BONE AND CARTILAGE
}

\author{
C.H. Evans ${ }^{1,2,3^{*}}$, F.-J. Liu' ${ }^{1,2}$, V. Glatt ${ }^{2}$, J.A. Hoyland ${ }^{4}$, C. Kirker-Head ${ }^{5}$, A. Walsh ${ }^{5}$, O. Betz ${ }^{1}$, J.W. Wells ${ }^{1,2}$, V. Betz ${ }^{1,6}$, \\ R.M. Porter ${ }^{1,2}$, F.A. Saad ${ }^{7}$, L.C. Gerstenfeld ${ }^{8}$, T.A. Einhorn ${ }^{8}$, M.B. Harris ${ }^{9}$, and M.S. Vrahas ${ }^{3,6}$
}
${ }^{1}$ Center for Molecular Orthopaedics, Brigham and Women's Hospital, Harvard Medical School, Boston, MA, USA
${ }^{2}$ Center for Advanced Orthopaedic Studies, Beth Israel Deaconess Medical Center, Harvard Medical School, Boston, MA, USA
${ }^{3}$ Collaborative Research Center, AO Foundation
${ }^{4}$ Tissue Injury and Repair Research Group, University of Manchester, Manchester, UK
${ }^{5}$ Orthopaedic Research Laboratory, Tufts Cummings School of Veterinary Medicine, Grafton, MA, USA
${ }^{6}$ Department of Orthopaedic Surgery, Massachusetts General Hospital, Boston, MA, USA
${ }^{7}$ Department of Orthopaedic Surgery, Children's Hospital, Boston, MA, USA
${ }^{8}$ Department of Orthopedic Surgery, Boston University Medical Center, Boston, MA, USA
${ }^{9}$ Department of Orthopaedic Surgery, Brigham and Women's Hospital, Boston, MA, USA

\begin{abstract}
We report a novel technology for the rapid healing of large osseous and chondral defects, based upon the genetic modification of autologous skeletal muscle and fat grafts. These tissues were selected because they not only possess mesenchymal progenitor cells and scaffolding properties, but also can be biopsied, genetically modified and returned to the patient in a single operative session. First generation adenovirus vector carrying cDNA encoding human bone morphogenetic protein-2 (Ad.BMP-2) was used for gene transfer to biopsies of muscle and fat. To assess bone healing, the genetically modified ("gene activated") tissues were implanted into 5mm-long critical size, mid-diaphyseal, stabilized defects in the femora of Fischer rats. Unlike control defects, those receiving gene-activated muscle underwent rapid healing, with evidence of radiologic bridging as early as 10 days after implantation and restoration of full mechanical strength by 8 weeks. Histologic analysis suggests that the grafts rapidly differentiated into cartilage, followed by efficient endochondral ossification. Fluorescence in situ hybridization detection of Y-chromosomes following the transfer of male donor muscle into female rats demonstrated that at least some of the osteoblasts of the healed bone were derived from donor muscle. Gene activated fat also healed critical sized defects, but less quickly than muscle and with more variability. Anti-adenovirus antibodies were not detected. Pilot studies in a rabbit osteochondral defect model demonstrated the promise of this technology for healing cartilage defects. Further development of these methods should provide ways to heal bone and cartilage more expeditiously, and at lower cost, than is presently possible.
\end{abstract}

Keywords: Adenovirus, bone morphogenetic protein, large segmental defects, cartilage repair, bone healing, gene therapy, animal models, facilitated endogenous repair, tissue engineering, fibrodysplasia ossificans progressiva.
*Address for correspondence

Chris Evans

Center for Advanced Orthopaedic Studies

Beth Israel Deaconess Medical Center

330, Brookline Avenue RN-115

Boston MA 02215, USA

Telephone Number: +1 617-667-4621

FAX Number: +1 617-667-7175

E-mail: cevans@bidmc.harvard.edu

\section{Introduction}

Tissue engineering approaches to the repair of bone and cartilage often require the ex vivo expansion of autologous progenitor cells which are seeded onto scaffolds and incubated in the presence of morphogens to induce differentiation. The engineered tissues are then surgically implanted during a subsequent procedure. Facilitated endogenous repair is an alternative strategy that seeks to expedite the process by delivering genes intraoperatively to minimally manipulated, autologous tissues that contain progenitor cells and possess the properties of a spacefilling, inductive or conductive scaffold (Evans et al., 2007). The use of genetically modified bone marrow coagulates for cartilage repair is one example of this approach (Ivkovic et al., 2010; Pascher et al., 2004). As noted in previous publications (Evans et al., 2007), muscle and fat are also candidates for use in facilitated endogenous repair. Here we confirm their ability to promote the rapid healing of bone and osteochondral defects in animal models.

As demonstrated by the disease fibrodysplasia ossificans progressiva (FOP), human muscle has an enormous capacity to form bone in vivo (Kaplan et al., 2008). The propensity for bone to form in muscle is also demonstrated by the frequency of heterotopic ossification in patients undergoing total hip joint replacement (Stoltny et al., 2007) and following blast injuries (Forsberg et al., 2009). Patients with FOP contain an activating mutation in the gene encoding a bone morphogenetic protein (BMP) type I receptor (Shore et al., 2006), suggesting that human muscle forms bone very efficiently in response to BMP signalling. Gene transfer provides one way to deliver a 
sustained BMP signal (Evans et al., 2004), and we have extensively used an adenovirus vector (Ad.BMP-2) for this purpose (Baltzer et al., 2000a; Baltzer et al., 2000b; Betz et al., 2007a; Betz et al., 2006; Betz et al., 2007b; Betz et al., 2008; Lieberman et al., 2002). Previous studies in which a recombinant adenovirus vector was injected directly into femoral segmental defects created in experimental animals have shown that nearly all the transgene is expressed in the muscle surrounding the defect (Baltzer et al., 1999). The possibility that genetically modified muscle cells make important contributions to healing of the adjacent lesion is suggested by the demonstration of osteoprogenitor cells within skeletal muscle (Bosch et al., 2000; Mastrogiacomo et al., 2005). Here we have examined directly the hypothesis that skeletal muscle has the ability to form bone and heal critical sized osseous defects when transduced with Ad.BMP-2. Fat is another tissue known to possess osteoprogenitor cells (Dragoo et al., 2005) and to have the ability to serve as a space-filling scaffold. It is readily recovered by, for instance, liposuction and is thus also of interest for facilitated endogenous repair.

Because progenitor cells within muscle and fat can also differentiate into chondrocytes (Kuroda et al., 2006; Mastrogiacomo et al., 2005; Wickham et al., 2003), there is the potential to use these tissues as the basis for healing chondral and osteochondral lesions. The literature suggests that recombinant BMP-2 can be used for cartilage repair (Sellers et al., 1997; Sellers et al., 2000), despite concerns about its ability to induce the hypertrophic differentiation of chondrocytes as a prelude to bone formation (Steinert et al., 2009). Thus, we have also performed a pilot study to determine whether grafts of muscle or fat that have been transduced with Ad.BMP-2 are able to heal osteochondral defects in the femoral condyles and trochlear grooves of rabbits' knees.

Collectively, the data confirm the merits of this approach to tissue repair and shed light on the importance of local, in vivo cues for determining mesenchymal cell differentiation pathways.

\section{Materials and Methods}

\section{Vectors and transduction of muscle and fat}

First generation adenovirus $(\Delta \mathrm{E} 1, \Delta \mathrm{E} 3)$, serotype 5, carrying human BMP-2 cDNA (Ad.BMP-2), firefly luciferase cDNA (Ad.luc) or green fluorescent protein cDNA (Ad.GFP) under the transcriptional control of the human cytomegalovirus early promoter were constructed by cre-lox recombination (Hardy et al., 1997) as previously described (Gouze et al., 2004; Palmer et al., 2003). Viruses were propagated in 293 cells (ATCC, Manassas, VA, USA), purified on caesium-chloride gradients, and dialysed against $10 \mathrm{mM}$ Tris- $\mathrm{HCl}$ (pH 7.8), $150 \mathrm{mM} \mathrm{NaCl}, 10 \mathrm{mM}$ $\mathrm{MgCl}_{2}$, and $4 \%$ sucrose buffer. Viral titres were estimated as $10^{22}$ to $10^{13}$ particles $/ \mathrm{ml}$ by optical density and $10^{10}$ to $10^{11}$ plaque forming units ( $\left.\mathrm{pfu}\right) / \mathrm{ml}$ by standard plaque assay (Gouze et al., 2004; Palmer et al., 2003).

Skeletal muscle and fat tissue to be subsequently implanted were harvested aseptically from donor animals, placed into 50ml Falcon tubes with complete Dulbecco's Modified Essential Medium (DMEM), and transferred to the laboratory for transduction with adenovirus vectors. Tissues were carefully cut into $1 \mathrm{~mm}$ thick slices in Petri dishes and a skin biopsy punch, diameter $4 \mathrm{~mm}$, was used to punch out uniform, standard $4 \mathrm{~mm} \times 1 \mathrm{~mm}$ discs. Tissue discs were placed into 24-well plates and transduced with the indicated amounts of adenovirus particles. A $20 \mu \mathrm{l}$ suspension of adenovirus was directly dropped onto the surface of tissue disc in the wells. The plates were returned to the incubator $\left(37^{\circ} \mathrm{C}\right.$ and $\left.5 \% \mathrm{CO}_{2}\right)$ for $60 \mathrm{~min}$. Afterwards $1 \mathrm{ml}$ complete DMEM supplemented with $10 \%$ foetal bovine serum and $1 \%$ antibiotics was added to each well, and incubation continued for another $60 \mathrm{~min}$. After removing the transduction medium, $1 \mathrm{ml}$ fresh complete DMEM medium was added to each well and incubation continued for 3 days. Conditioned media were collected and BMP-2 concentrations were measured using a commercial ELISA kit (R\&D Systems, Minneapolis, MN, USA).

\section{In vitro experiments}

To estimate the efficiency of gene transfer to cells within muscle and fat, discs of these tissues were recovered from rats and transduced with Ad.GFP or Ad.BMP-2, as described above. $\mathrm{GFP}^{+}$cells were identified by fluorescence microscopy, and BMP-2 expression was determined by ELISA measurement of conditioned media. All in vitro experiments were repeated in triplicate.

To evaluate a possible osteogenic response of muscle to transduction with Ad.BMP-2, discs of transduced and control muscle were maintained in 24-well plates with $1 \mathrm{ml}$ DMEM medium supplemented with $10 \%$ foetal bovine serum and antibiotics. At 10 and 21 days, discs were recovered, RNA isolated and the abundance of bone and muscle specific transcripts measured by quantitative, real time PCR. Discs were homogenized together in TRIzol ${ }^{\circledR}$ (Invitrogen, Carlsbad, CA, USA), mixed with chloroform, and RNA was precipitated with isopropanol. After quantification, RNA integrity was checked by agarose gel electrophoresis. Oligotex ${ }^{\circledR}$ (Qiagen, Valencia, CA, USA), mRNA purification reagent, was used to purify mRNA from total RNA according to standard protocols.

RETROscript $^{\mathrm{TM}}$ (Ambion, Austin, TX, USA) first strand synthesis kit was used to reverse transcribe mRNA to cDNA according to standard protocols. In brief, mRNA (100 ng) was reverse transcribed with M-MLV reverse transcriptase in $20 \mu \mathrm{l}$. The cDNA was diluted $5 \mathrm{X}$ and used as template for RT-PCR. Real-time quantitative RT-PCR was used to evaluate mRNA levels using an ABI PRISM ${ }^{\circledR}$ 7700 sequence detection system (Applied Biosystems, Foster City, CA, USA). We have previously described the real-time RT-PCR conditions (Hofstaetter et al., 2004; Hofstaetter et al., 2005; Hofstaetter et al., 2007). Briefly, the reactions were run in triplicate, each containing $1 \mu \mathrm{l}$ cDNA along with 2.5 pmoles of gene specific primers (Table 1) in a final volume of $25 \mu \mathrm{l}$ with the following thermal profile: $5 \mathrm{~min}$ initial denaturing step to activate the DNA polymerase, then 40 cycles each at $95^{\circ} \mathrm{C}$ for 35 sec, $60^{\circ} \mathrm{C}$ for $45 \mathrm{sec}$, and $72^{\circ} \mathrm{C}$ for $45 \mathrm{sec}$. Levels of GAPDH transcript proved to be stable under the 
Table 1. Primers used to amplify rat bone and muscle markers

\begin{tabular}{|c|c|c|c|}
\hline $\begin{array}{c}\text { Gene primer sequences } \\
5 \text { ' to 3' }\end{array}$ & Td & Amplicon & Accession number \\
\hline \multicolumn{4}{|l|}{ Bone markers } \\
\hline Rat Osteocalcin & & $285 \mathrm{bp}$ & M23637 \\
\hline F gcc cag cga ctc tga gtc tg & 67.2 & & \\
\hline $\mathrm{R}$ cca atg tgg tcc get agc tc & 67.2 & & \\
\hline Rat Bone Sialoprotein & & $264 \mathrm{bp}$ & DQ213013 \\
\hline F gta ccg gcc acg cta ctt tc & 66.5 & & \\
\hline R cca gcg tca get gtg gtc tc & 68.0 & & \\
\hline Rat Alkaline phosphatase & & $260 \mathrm{bp}$ & J03572 \\
\hline F ccc tgc aac cat cat gga ac & 67.4 & & \\
\hline R gaa ggg ttg gcg agt ctc tg & 66.2 & & \\
\hline Rat Osteopontin & & $289 \mathrm{bp}$ & M14656 \\
\hline F gcc agc ctg gaa cat cag ag & 67.1 & & \\
\hline $\mathrm{R}$ aag ctc agg gcc caa aac ac & 68.2 & & \\
\hline Rat Collagen I alpha 1 & & 275 bp & XM_213440 \\
\hline F ggg gtg gga agg aat ttc tg & 67.3 & & \\
\hline R tag gga gca gca gca aga gg & 67.2 & & \\
\hline Rat $C b f a 1$ & & $221 \mathrm{bp}$ & AB025797 \\
\hline F agt ggc cag gtt caa cga tc & 66.3 & & \\
\hline R tgc gcc cta aat cac tga gg & 67.8 & & \\
\hline \multicolumn{4}{|l|}{$\underline{\text { Muscle markers }}$} \\
\hline Rat Myosin 1 & & $250 \mathrm{bp}$ & X68199 \\
\hline F aag cag cta gta agg gtg act ttc & 65.2 & & \\
\hline R ctc act taa ggg aca gcg act tc & 66.7 & & \\
\hline Rat Actin alpha & & 329 bp & NM_019183 \\
\hline F tcc cag cac cat gaa gat taa $g$ & 66.1 & & \\
\hline R agg ttg caa gtc ctg gtc tg & 64.0 & & \\
\hline \multicolumn{4}{|l|}{ Housekeeping gene } \\
\hline Rat Gapdh & & $188 \mathrm{bp}$ & AF106860 \\
\hline F aag ggc atc ctg ggc tac ac & 68.0 & & \\
\hline $\mathrm{R}$ gag gcc atg tag gcc atg ag & 66.9 & & \\
\hline
\end{tabular}

experimental trials; therefore it was selected as a reference gene. The SYBR green detection system was used. Relative Expression Software Tool $\left(\mathrm{REST}^{\odot}\right)$ was used to analyze mRNA expression levels, $\mathrm{C}_{\mathrm{t}}$ values (Pfaffl, 2001; Pfaffl et al., 2002), with data expressed as fold induction relative to controls.

Other discs were used to assay alkaline phosphatase (ALP) enzyme activity using a colorimetric assay based upon the conversion of $\mathrm{p}$-nitrophenol phosphate to $\mathrm{p}$ nitrophenol using a commercially available kit (Sigma Chemical Co., St Louis, MO, USA). To determine whether the genetically modified discs deposited mineral, certain samples were processed for histology, as described below, and stained with alizarin red.

\section{Rat femoral segmental defect model}

Because rats are too small for convenient autografting, donor rats were euthanized and used as a source of muscle and fat, harvested from the thighs. Initially, SpragueDawley rats were used for this purpose, but gave variable results. Once informed that this strain of rat is not completely syngeneic, Fischer rats were used because individuals within this strain are completely inbred and can thus accept transplants from other Fischer rats without mounting an allograft response (T.J. Gill, personal communication, December 2005). For most experiments, groups of 10 rats per group were used.

Segmental defects, $5 \mathrm{~mm}$ in length were created in the right femora of adult male rats weighing 400-425g, using 
the methods described in detail by Betz et al. (2006). Briefly, animals were anaesthetised with isofluorane and the right femur surgically exposed. An external fixator (described in Betz et al., 2006) was attached to the femur and a 5-mm osteotomy was then performed with use of a sterile, round dental burr attached to a dental handpiece. Test materials were then placed into the defect (Fig. 1). After copious irrigation, the surgical site was closed in layers and antibiotics and analgesics administered.

As a positive control, defects received $11 \mu \mathrm{g}$ rhBMP-2 (produced in $\mathrm{CHO}$ cells) delivered on a collagen sponge. Negative controls received unmodified fat or muscle, or fat and muscle that had been transduced with Ad.luc or Ad.GFP. Other negative controls received nothing and remained as empty defects. In the first series of experiments, defects were monitored by weekly radiography and animals were euthanized by $\mathrm{CO}_{2}$ asphyxiation eight weeks after surgery. The quality of the healed bone was evaluated post-mortem by dual-energy X-ray absorptiometry (DXA), micro-computed tomography $(\mu \mathrm{CT})$, mechanical testing in torsion and

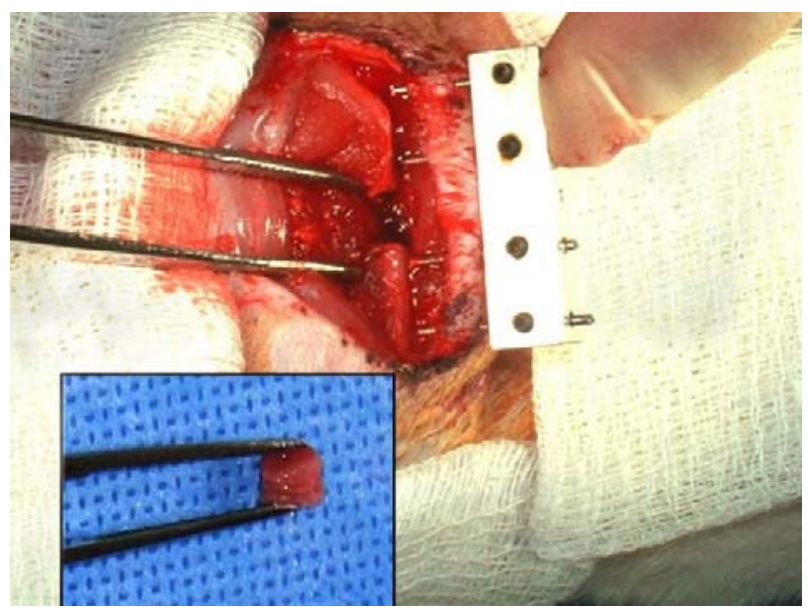

Figure 1. Insertion of genetically modified muscle into femoral defect. Intraoperative image showing the $5 \mathrm{~mm}$ femoral defect with external fixator in place. Inset shows a stack of muscle discs ready to be inserted into the defect. a

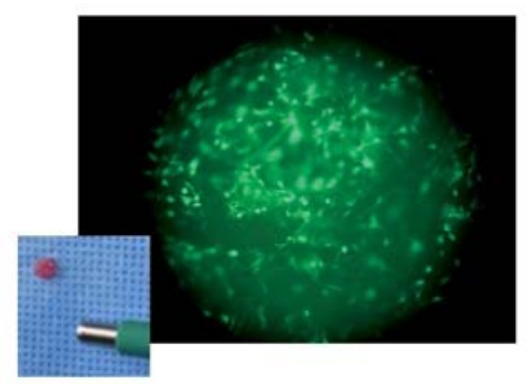

b

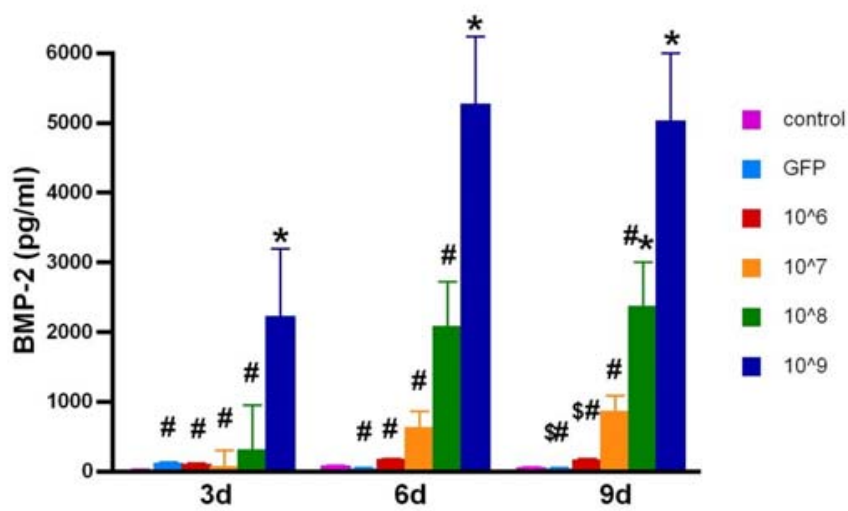

C
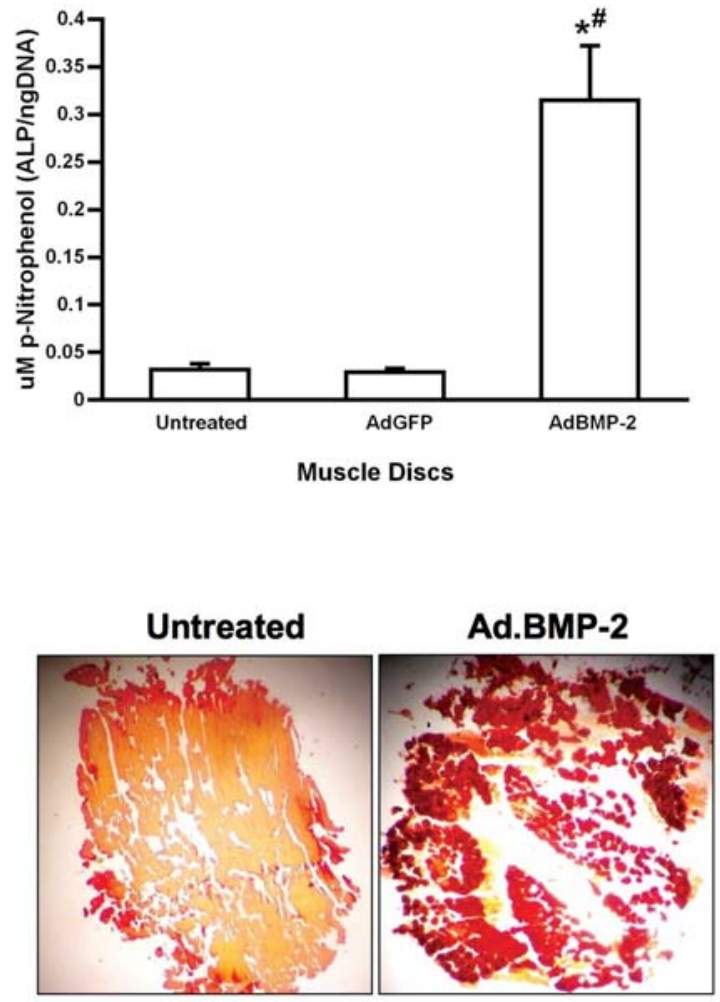

Figure 2. In vitro genetic transduction and osteogenic responses of rat muscle discs.

(a) $4 \mathrm{~mm}$ diameter disc of rat muscle after transduction with Ad.GFP, viewed under fluorescence microscopy. Inset shows freshly isolated disc near the end of the tissue punch.

(b) Production of BMP-2 following transduction with Ad.BMP-2. Discs were transduced with $10^{6}, 10^{7}, 10^{8}$ or $10^{9}$ pfu Ad.BMP-2. Control discs received $10^{9} \mathrm{pfu}$ Ad.GFP or remained untransduced. Media were changed every 3 days and BMP-2 concentrations determined by ELISA. Symbols: *- significant difference from control, \# - significant difference from discs transduced with $10^{9} \mathrm{pfu}$ Ad.BMP-2, $\$$ - significant difference from discs transduced with $10^{8}$ pfu Ad.BMP-2.

(c) Alkaline phosphatase activity of naïve muscle discs, and discs transduced with Ad.BMP-2 or Ad.GFP. *-significant difference from untreated disc, \# - significant difference from disc transduced with Ad.GFP

(d) Alizarin red staining of untreated muscle discs and discs transduced with Ad.BMP-2 at 21 days. 

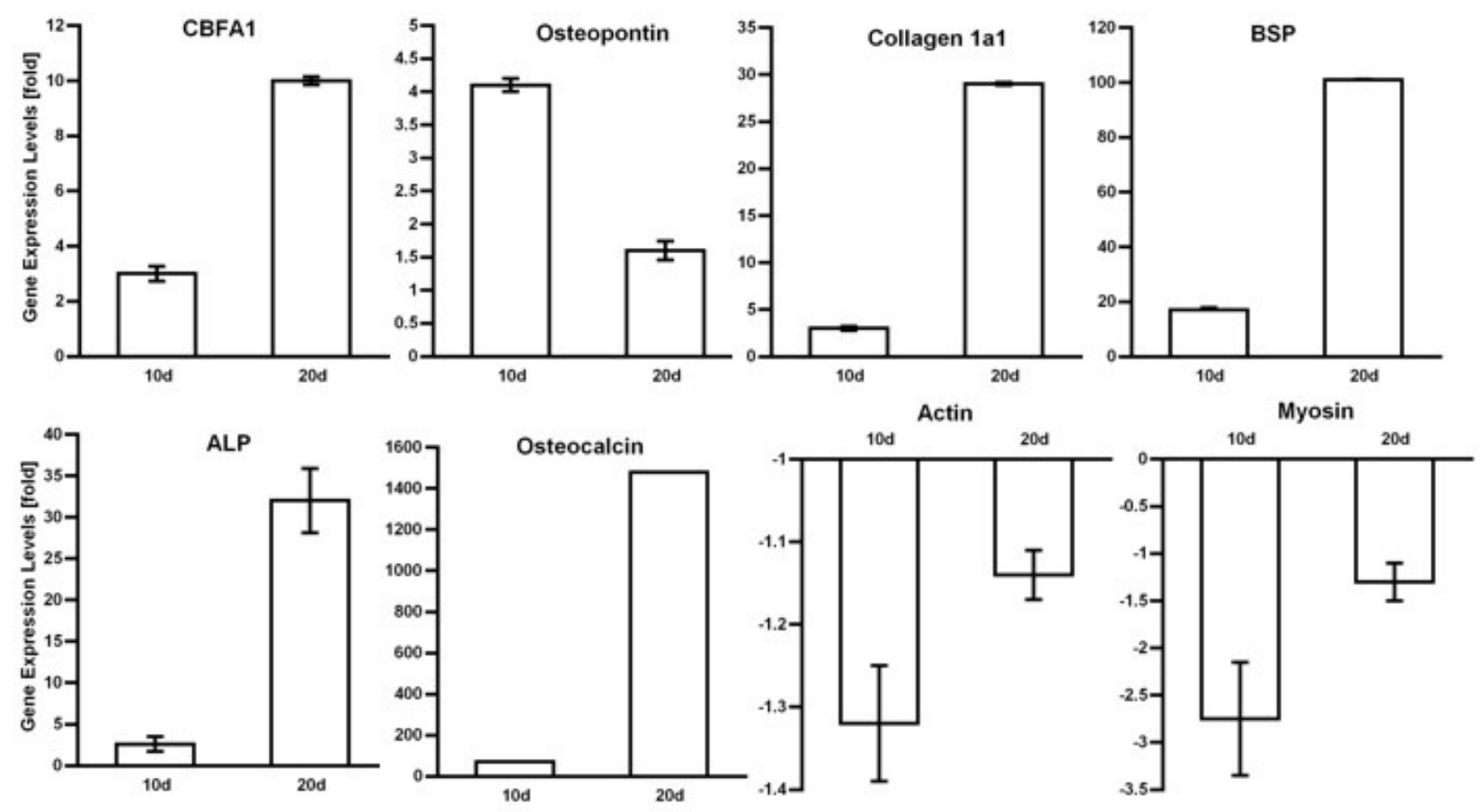

Figure 3. Expression of bone and muscle related genes by muscle discs after transduction with Ad.BMP-2. RNA was extracted and quantitative, real-time PCR performed 10 and 21 days after gene transfer using the techniques described in Materials and Methods. Expression is expressed as fold induction or reduction compared to controls. $\mathrm{BSP}=$ bone sialoprotein; ALP = alkaline phosphatase.

histology. In certain experiments, control animals receiving unmodified muscle were euthanized after 12 weeks.

\section{Dual-energy X-ray absorptiometry (DXA)}

We assessed the bone mineral content $(\mathrm{g})$ of the defect region by dual-energy X-ray absorptiometry (PIXImus 2; GE-Lunar, Madison, WI, USA). Specimens were placed on a Lucite block during scanning to simulate soft tissue. The scans were acquired using small animal highresolution mode. All excised femora were evaluated after 8 weeks of treatment in the area corresponding to the region of the critical-sized segmental bone defect.

\section{Microcomputed tomography $(\mu \mathrm{CT})$}

All femora were scanned using a desktop microtomographic imaging system ( $\mu$ CT40; Scanco Medical AG, Bassersdorf, Switzerland) equipped with a $10 \mathrm{~mm}$ focal spot microfocus X-ray tube. Femora were scanned using a $16 \mathrm{~mm}$ isotropic voxel size at $55 \mathrm{keV}$ energy, 200ms integration time with approximately 720 $\mu \mathrm{CT}$ slices per specimen. Evaluation was done only in the $4 \mathrm{~mm}$ central defect region to ensure that no pre-existing cortical bone was included in the analyses. To evaluate the region of interest, we assessed the following variables: total cross-sectional area of the defect $\left(\mathrm{mm}^{2}\right)$ and bone area $\left(\mathrm{mm}^{2}\right)$. Images were thresholded using an adaptiveiterative algorithm and morphometric variables were computed from the binarized images using direct, threedimensional techniques that do not rely on any prior assumptions about the underlying structure.

\section{Ex vivo torsion testing}

After all noninvasive imaging was complete specimens were tested to failure in torsion to determine healed defect mechanical properties in shear. Both ends of each specimen were embedded in PMMA to provide a reproducible gripping interface with the testing fixture. All femora were tested to failure under regular deformation control and at the constant deformation rate of $5 \mathrm{rad} / \mathrm{min}$. Angular deformation and applied load data were acquired at $10 \mathrm{~Hz}$. The torque and rotation data were used to calculate the torsional stiffness and strength of the healed defect.

\section{Histology}

After evaluation by $\mu \mathrm{CT}$ and DXA the specimens were decalcified for 6 to 8 hours in RDO Rapid decalcifier (Apex Engineering, Aurora, IL, USA) testing with a needle as the decalcification proceeded. Fixed and decalcified tissues were dehydrated in graded ethanol up to $100 \%$, transferred to xylene, and embedded in paraffin. Five-micron paraffin sections were placed on poly L-lysine-coated slides, dried overnight, and evaluated immediately or stored at $4^{\circ} \mathrm{C}$. Sections were stained with safranin $\mathrm{O}$-fast green to detect the presence of cartilage or alizarin red to detect mineralized deposits.

\section{Fluorescence in situ hybridization (FISH)}

FISH was performed with the rat Y/12 chromosome paint (Cambio, Cambridge, UK), according to the manufacturer's instructions. Briefly, tissue sections were de-waxed in xylene, transferred to industrial methylated spirits and then washed in $0.4 \%$ sodium thiocyanate at $80^{\circ} \mathrm{C}$ 


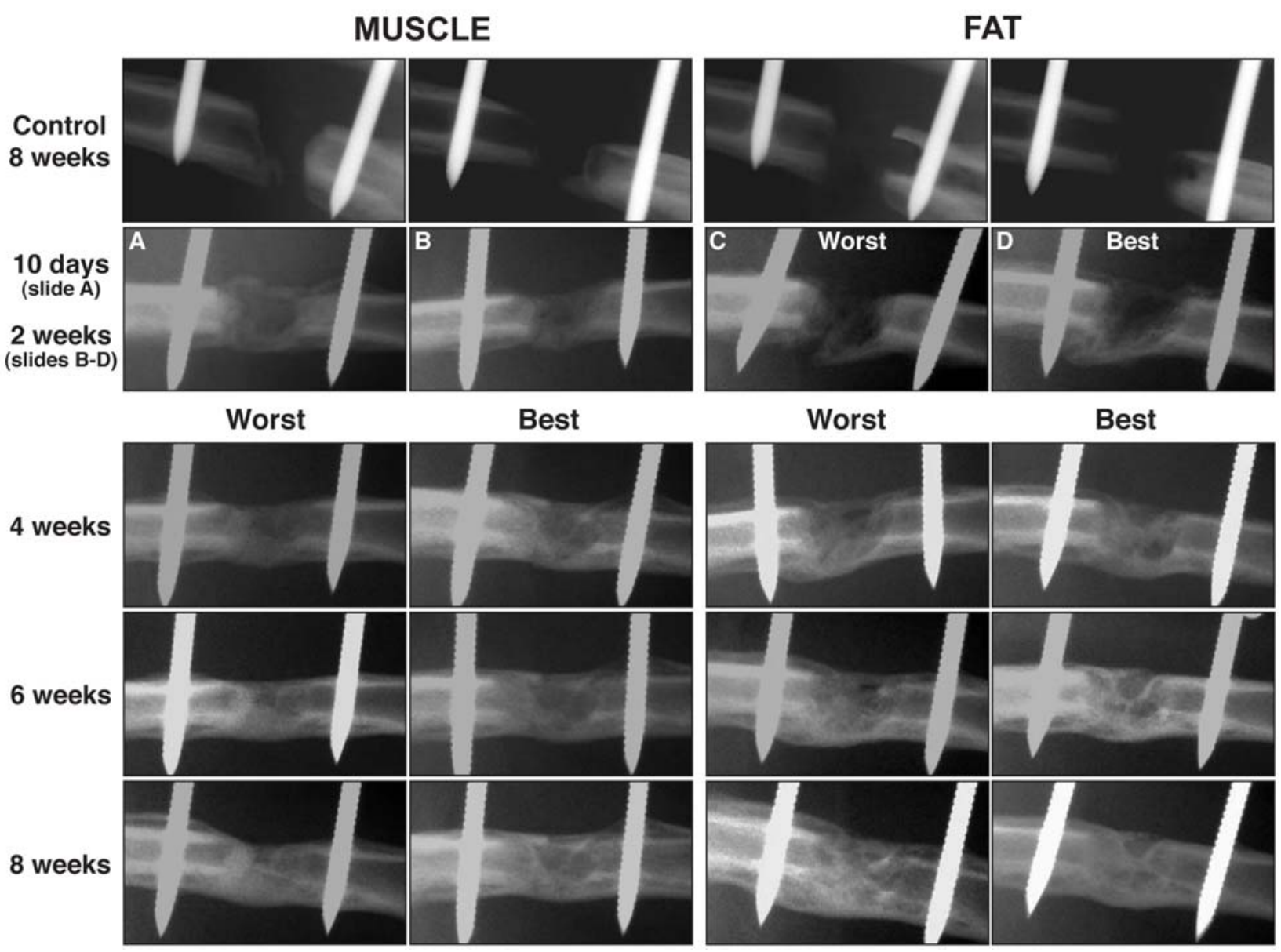

Figure 4. Serial radiographs of defects in rat femora following the implantation of gene-activated muscle and fat grafts. Control defects received tissue grafts transduced with control virus carrying marker genes. Radiologic bridging can be seen in as little as 10 days when using Ad.BMP-2 modified muscle grafts. Healing is slower using Ad.BMP2 modified fat, with radiolucency at 10 days, and bridging seen only by 2 weeks. Images from 2 weeks onward (fat) and 4 weeks onwards (muscle) show the best and worst healers, based on radiologic appearance, in each group of 10 rats.

for 10 minutes. Sections were then permeabilised with $0.4 \%$ pepsin $/ 0.1 \mathrm{M} \mathrm{HCl}$. Following permeabilisation, sections were post fixed in $4 \%$ paraformaldehyde/ phosphate buffered saline (PBS), dehydrated and air-dried. Chromosome paint $(15 \mu \mathrm{l})$ was applied to each section and sections were denatured at $60^{\circ} \mathrm{C}$ for 10 minutes and then left to hybridise overnight at $37^{\circ} \mathrm{C}$. Following hybridization a series of stringency washes were performed at $37^{\circ} \mathrm{C}(50 /$ 50 deionised formamide $/ 2 \mathrm{X}$ sodium chloride-sodium citrate (SSC) for 15 minutes; 2 X SSC for $15 \mathrm{~min}$; 4 X SSC containing $0.1 \mathrm{ml} 10 \%$ Tween 20 ) and then slides were washed in PBS. Sections were then mounted using ProLong Gold anti-fade reagent with DAPI (Invitrogen) and allowed to cure for $24 \mathrm{hrs}$ at room temperature in the dark. All slides were analyzed with a Zeiss (www.zeiss.com) fluorescence microscope. The Y-FISH probe was validated using rat testes.

\section{Immunological methods}

Peripheral blood was recovered from 3 rats that had received unmodified muscle, 3 rats that had received geneactivated muscle or fat, and 3 rats that had been injected intra-dermally with $5.5 \times 10^{10}$ viral particles Ad.BMP-2 (positive control).
Levels of anti-adenovirus antibodies in sera were assessed by ELISA. Standard 96-well Nunc ELISA plates were coated overnight with $5 \times 10^{9}$ adenoviral particles $/ \mathrm{ml}$ suspended in phosphate buffered saline (PBS) (50 $\mu \mathrm{l} /$ well). Plates were blocked by a 1 -hour incubation with $1 \%$ Bovine Serum Albumin/PBS (100 $\mu 1 /$ well). Serum samples were subjected to serial dilution in $\mathrm{PBS} / 0.5 \% \mathrm{FCS} / 0.5 \%$ Tween 20 and added to duplicate wells overnight $(50 \mu \mathrm{l} /$ well). Plates were then incubated with anti-rat IgG ALP conjugate diluted (1/2500) in PBS/0.5\% FCS/ $0.05 \%$ Tween 20 for 2 hours, washed, and subsequently incubated with $1 \mathrm{mg} / \mathrm{ml}$ p-nitro-phenyl phosphate substrate in order to detect plate-bound antibodies. The optical densities of the plates were read on a Precision Microplate Reader (Molecular Devices, Sunnyvale, CA, USA) at 405nm.

\section{Rabbit osteochondral defect model}

New Zealand white rabbits weighing $2.5 \mathrm{~kg}$ were used for this pilot study of 3 animals per group. Because these animals were large enough to provide autografts, subcutaneous fat and dorsal muscle biopsies were first removed from the rabbits and transduced with $10^{9} \mathrm{pfu}$ Ad.BMP-2, as described above. One week later, rabbits were anaesthetized and their right femoro-tibial joints were 

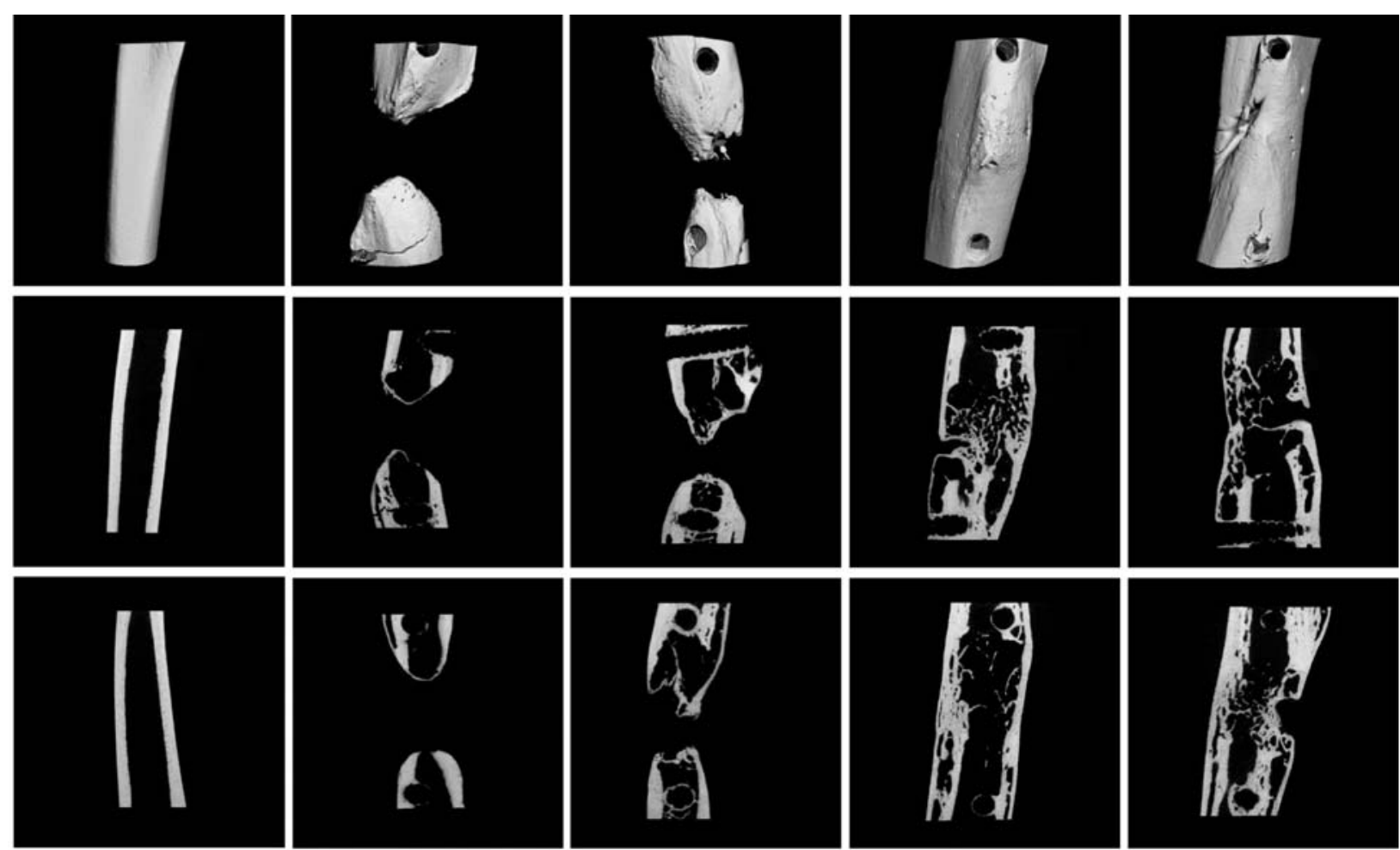

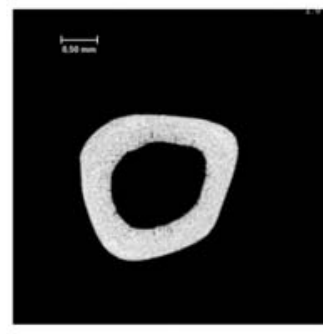

Contralateral Femur
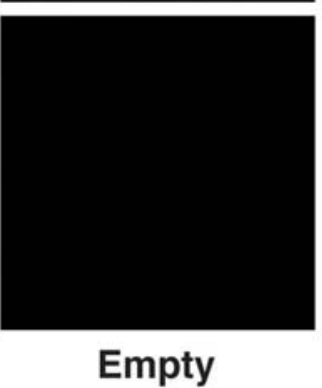

Control

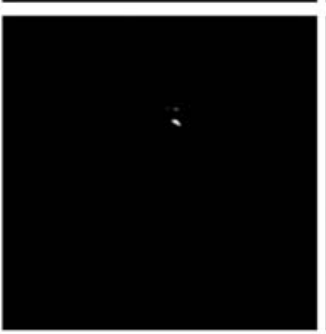

\section{Muscle \\ Only}

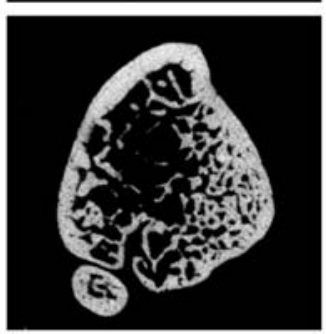

AdBMP-2

Activated Muscle Graft

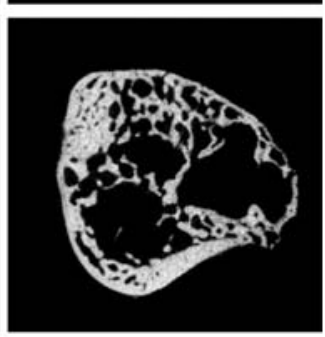

AdBMP-2

Activated

Fat Graft

Figure 5. Micro-computed tomography images 8 weeks after surgery. Images are shown three dimensionally (top row), in longitudinal sections (middle 2 rows) and cross section (bottom row).

surgically exposed. Osteochondral defects of $3 \mathrm{~mm}$ diameter and $6 \mathrm{~mm}$ depth were drilled into the trochlear groove or the medial femoral condyle. Defects were left as empty controls, implanted with unmodified tissue grafts or implanted with grafts that had been transduced with Ad.BMP-2. Rabbits were euthanized after 6 weeks and the distal femora removed for decalcification and paraffin histology, using safranin $\mathrm{O}$-fast green, as described above.

\section{Statistical Analysis}

Comparisons of continuous variables between two treatment groups were performed using a two-tailed t-test, and between three groups by analysis of variance (One Way-ANOVA). If the difference between the control and the treatment groups was significant, a post-hoc test (Tukey) was performed. Each in vitro experiment was repeated three times. Differences were considered statistically significant at $p<0.05$. Data are presented as mean \pm standard error (SE), unless otherwise noted.

\section{Results}

In vitro genetic modification and osteogenic differentiation of rat skeletal muscle

Discs of rat skeletal muscle were readily transduced with adenovirus vectors. As shown in Fig. 2a, large numbers of mononuclear cells within the biopsies became $\mathrm{GFP}^{+}$after transduction with Ad.GFP. Discs transduced with Ad.BMP-2 secreted BMP-2 into their culture media in a dose-dependent manner for at least 9 days, reaching a steady state concentration of approximately $5 \mathrm{ng} / \mathrm{ml}$ in a $72 \mathrm{~h}$ period (Fig. $2 \mathrm{~b}$ ) when $10^{9}$ pfu Ad.BMP-2 were used. Because the total culture volume is $1 \mathrm{ml}$, this equates to $5 \mathrm{ng}$ BMP-2/disc/72h. Induction of osteogenesis was indicated by expression of alkaline phosphatase activity in muscle discs transduced with Ad.BMP-2, but not Ad.GFP (Fig. 2c) and the deposition of a mineralized matrix (Fig. 2d).

Quantitative, real-time PCR measurements revealed that muscle discs transduced 10 or 20 days earlier with Ad.BMP-2 showed a dramatic induction of transcripts 


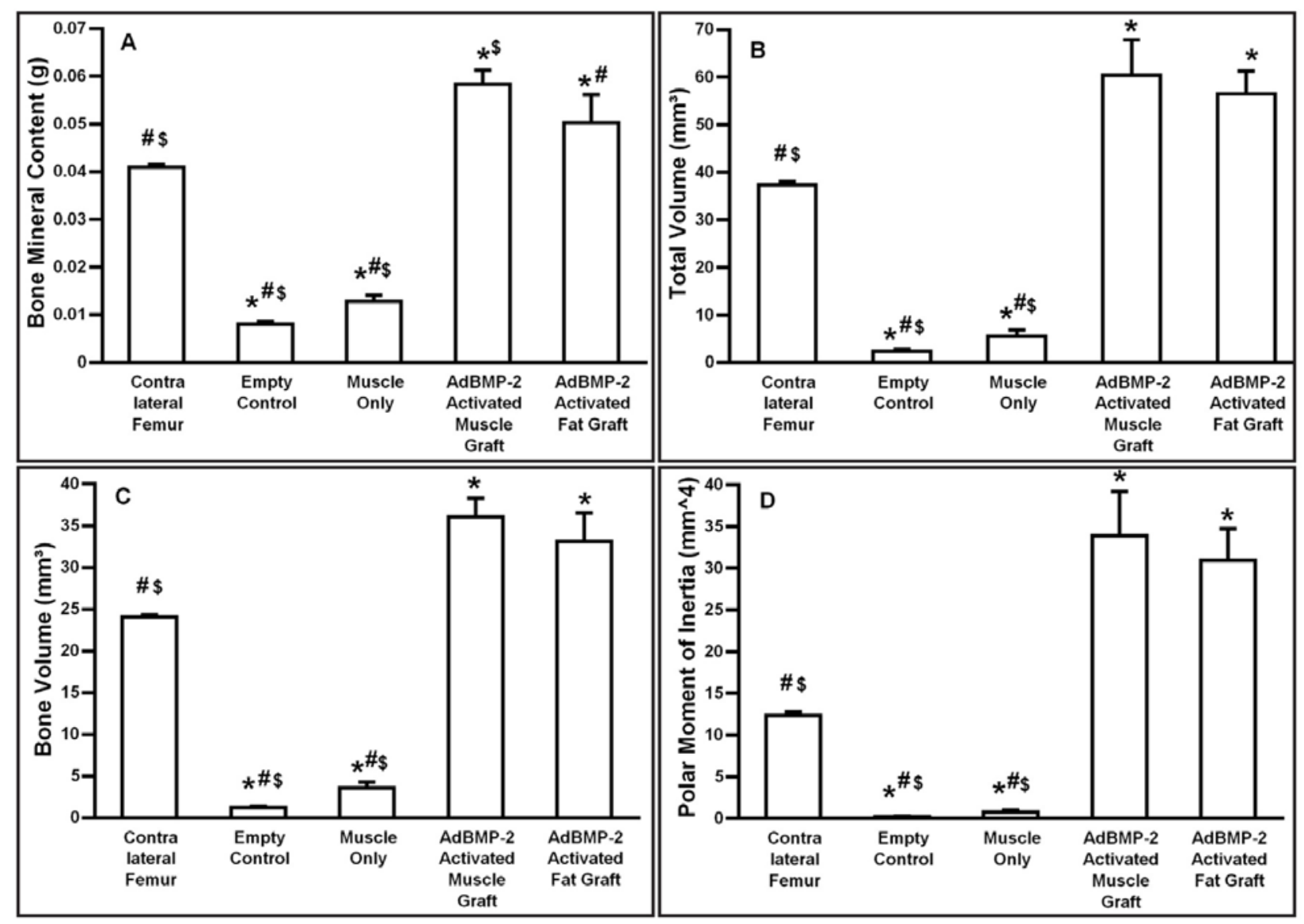

Figure 6. Quantitative data from micro-computed tomography and dual energy X-ray absorptiometry. Values given are means \pm standard deviation $(\mathrm{SD})(\mathrm{n}=10)$.

Symbols: *- significant difference from contralateral femur; \# - significant difference from AdBMP-2 activated muscle graft; $\$$ - significant difference from AdBMP-2 activated fat graft.
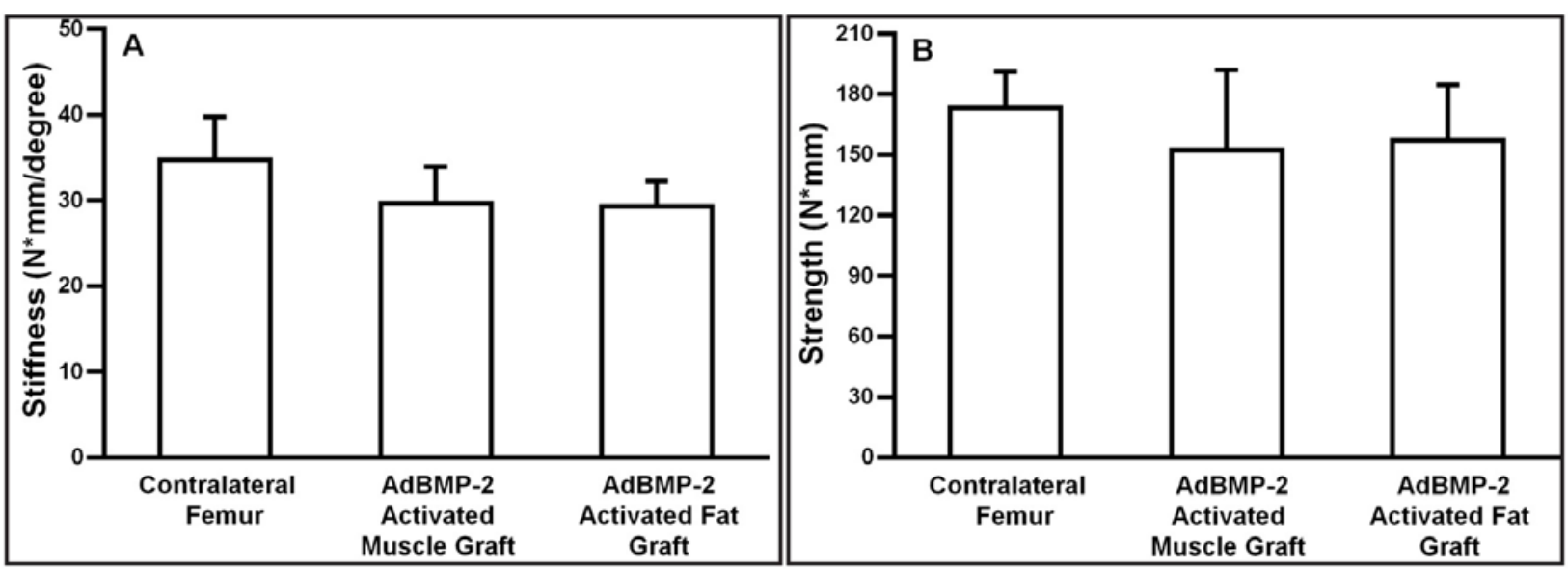

Figure 7. Mechanical properties of defects 8 weeks after implantation of Ad.BMP-2 activated muscle and fat. There are no statistically significant differences between the strength and stiffness values obtained with the contralateral femur, Ad.BMP-2 activated fat and Ad.BMP-2 activated muscle. Empty defects and control defects receiving unmodified or Ad.luc modified muscle and fat were too weak to be tested.

associated with osteogenesis, including the transcription factor CBFA1 (Runx2), osteopontin, Col1A1, bone sialoprotein (BSP), alkaline phosphatase (ALP) and osteocalcin. Transcripts encoding muscle specific actin and myosin, in contrast, were slightly reduced (Fig. 3). Although the Ad.BMP-2 transduced muscle expressed genes associated with osteogenesis and deposited a mineralized matrix, it retained the morphology of muscle (Fig. 2d).

\section{Repair of femoral segmental defects using genetically modified muscle}

The Sprague-Dawley rats used in initial experiments gave very variable results. In any group of animals, 

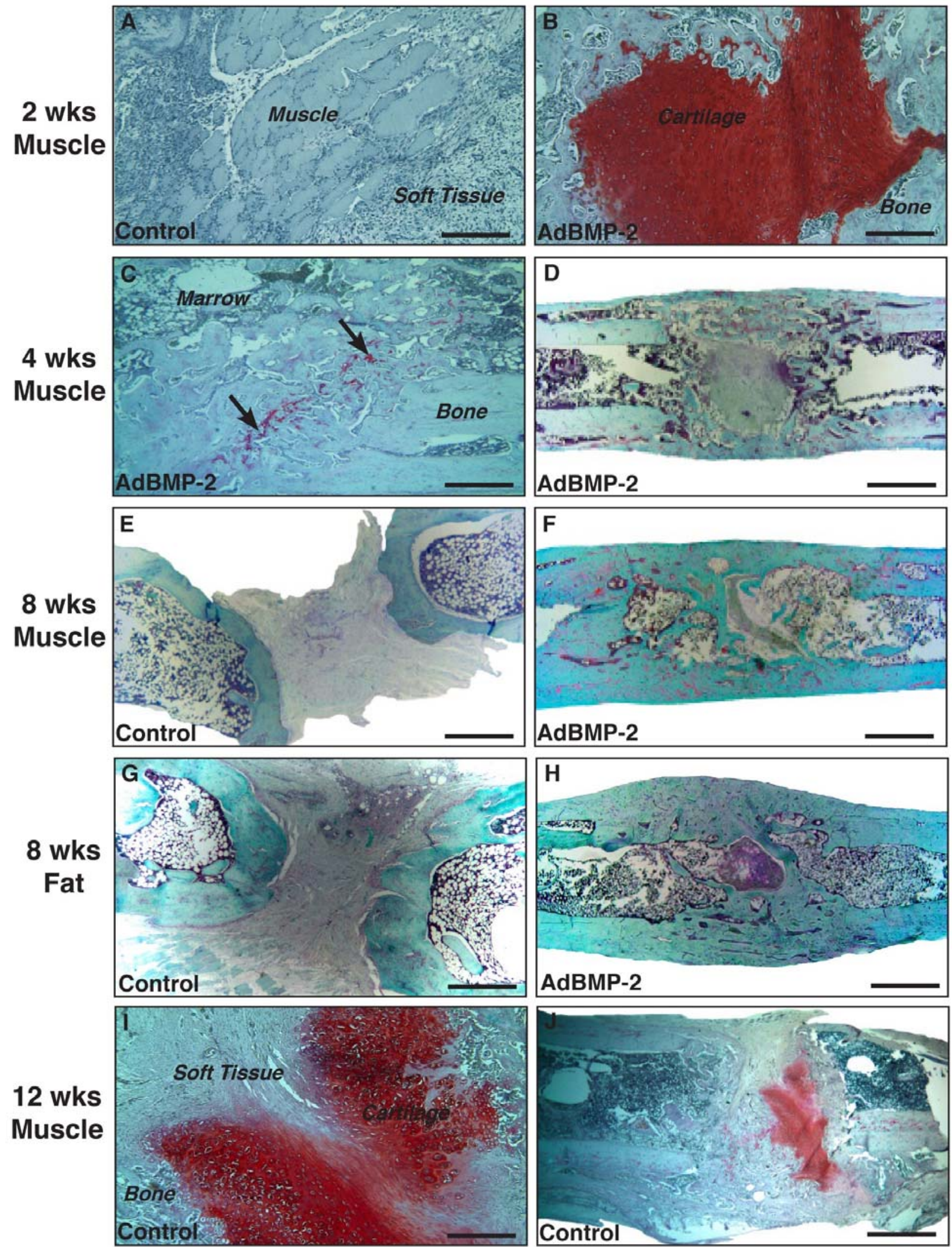

Figure 8. Histological examination of rat femora after implantation of gene-activated muscle and fat grafts. All sections were stained with safranin $\mathrm{O}$-fast green after euthanasia at the indicated time points after surgery. Low

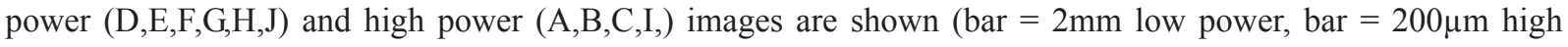
power). Arrows in panel $\mathrm{C}$ point to areas of residual proteoglycan. 

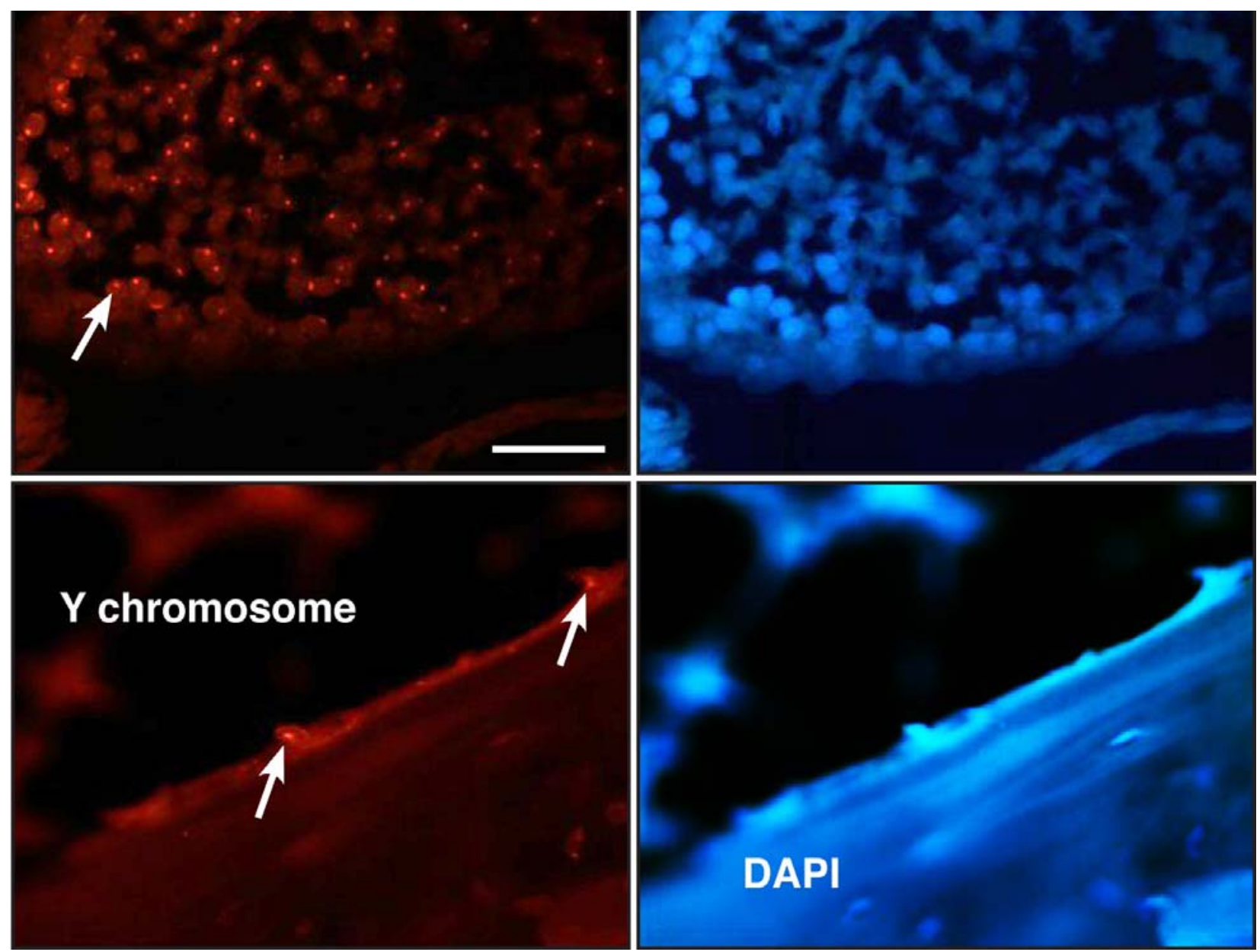

Figure 9. FISH identification of osteoblasts with Y-chromosomes in female rats. Femoral defects in female animals received Ad.BMP-2 transduced muscle from male donors. After 8 weeks, recipient rats were euthanized and sections stained with DAPI (right panels) or subjected to FISH (left panels) using probes specific for sequences unique to the Y-chromosomes of rats. The bottom left hand panel shows lining osteoblasts (arrowed) that possess a Ychromosome. Rat testis (top two panels) is shown as a positive control. A Y-chromosome positive testis cell is arrowed in the top, left panel. Bar $=100 \mu \mathrm{m}$

approximately one-third of the defects would undergo dramatic healing, one-third would heal slowly, and onethird would fail to heal (data not shown). It was pointed out that Sprague-Dawley rats are not syngeneic, unlike Fischer rats (T. J. Gill personal communication, December 2005). For this reason, all further experiments were conducted with Fischer rats.

Serial radiographs of the defects in Fischer rats confirmed that empty defects and control defects receiving unmodified muscle or muscle transduced with Ad.luc did not heal. Implantation of muscle discs transduced with Ad.BMP-2, in contrast, underwent rapid healing with evidence of bridging in as little as 10 days (Fig. 4). Healing was also notable because of the high degree of uniformity between the different rats in the group. Figure 4 shows the best and worst healers, based on radiologic appearance, at later time points; these are remarkably similar. Moreover, very little callus was evident.

$\mu \mathrm{CT}$ images taken eight weeks after surgery confirm healing in all Fischer rats receiving Ad.BMP-2 transduced muscle, but not controls (Fig. 5). In longitudinal and cross sectional imaging, $\mu \mathrm{CT}$ revealed the formation of cortical bone with presence of trabecular bone within the healed

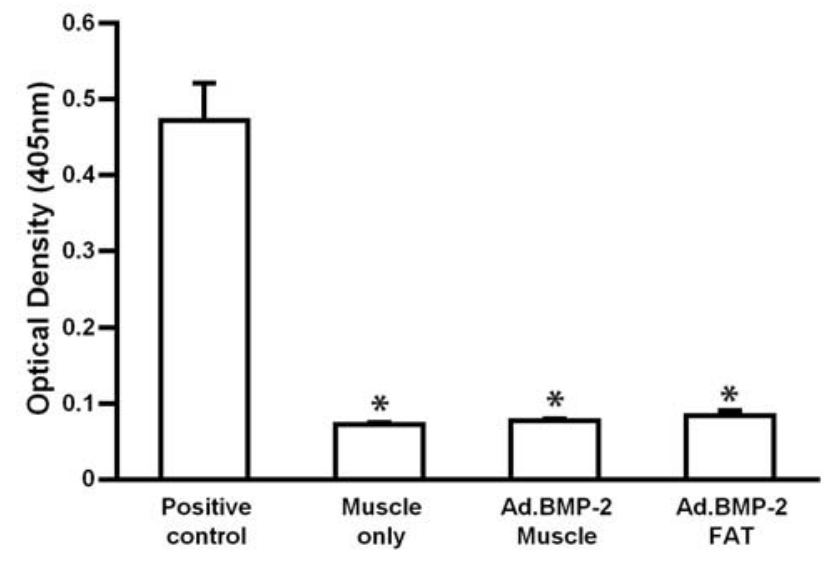

Figure 10. Humoral responses to adenovirus following implantation of transduced muscle and fat. ELISA measurement (units of optical density at $405 \mathrm{~nm}$ ) of antibody binding to adenovirus particles using serum obtained from rats receiving grafts of unmodified muscle, Ad.BMP-2 activated fat or Ad.BMP-2 activated muscle. As a positive control animals received an intradermal injection of Ad.BMP-2. Value are means $\pm \mathrm{SD} . *$ - significantly different from positive control. 

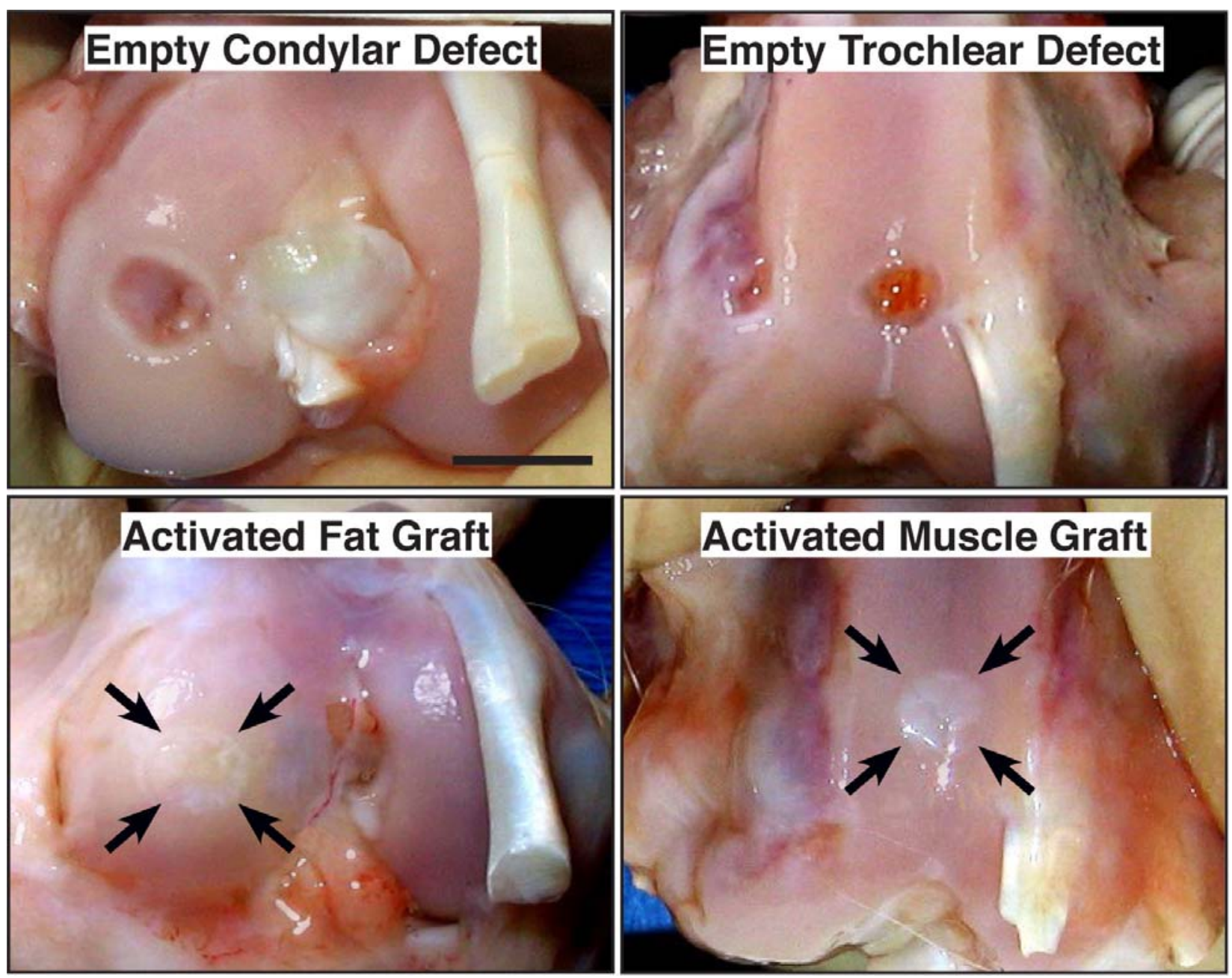

Figure 11. Macroscopic images of control osteochondral defects and defects treated with gene-activated muscle and fat. Rabbits were euthanized 6 weeks after surgery. Arrows indicate site of original defect and implantation of tissue. $\mathrm{Bar}=5 \mathrm{~mm}$

diaphyseal region of the femur. However, the smooth contours of the contralateral femur had not been restored by 8 weeks. Nevertheless, the quantitative $\mu \mathrm{CT}$ and DXA data (Fig. 6) demonstrate that the total volume, bone volume, polar moment of inertia and bone mineral content exceeded that of the contralateral femur, and full mechanical strength and stiffness had been restored (Fig. 7).

Histology was used to gain more information about the biological basis of the ability of the gene-activated muscle to heal the femoral defects in the Fischer rats (Fig. 8). Two weeks after the implantation of muscle discs modified with Ad.luc, sections showed only muscle surrounded by a highly cellular fibrous tissue (Fig. 8A). Many of the infiltrating cells appeared to be leucocytes, suggesting an inflammatory response. In sharp contrast, at the same 2-week time point there was no evidence of muscle in defects receiving muscle discs transduced with Ad.BMP-2. In its place, there was abundant cartilage as if the muscle had undergone chondrogenic differentiation en masse (Fig. 8B). Fibrous soft tissue was absent. The edges of the cartilage were surrounded by bone (hence the appearance of bridging on plane X-ray) and gave the appearance of hypertrophy and ossification. By 4 weeks (Figs. 8C, D) the cartilage had been almost entirely replaced by bone, the cortices were forming and marrow was present. Some residual soft tissue was apparent at this time in certain sections. By 8 weeks, healing was well advanced with abundant cortical and intramedullary bone (Fig. 8F), in agreement with the $\mu \mathrm{CT}$ images shown in Fig. 5. Control defects receiving muscle transduced with Ad.luc showed only amorphous soft issue within the defect at 8 weeks (Fig. 8E). Of interest, certain 12-week control defects that had received unmodified muscle showed evidence of spontaneous chondrogenesis (Figs. 8I,J). This was not associated with ossification.

To determine whether osteoblasts within the healed bone were of donor or host origin, we transferred geneactivated muscle from male donors into female recipients and identified cells at the recipient site containing a Ychromosome by FISH. As shown in Fig. 9, this method identified cells with Y-chromosomes on the surface of the healed bone, confirming that at least some of the osteoblasts in the repair tissue were of donor origin.

\section{Repair of femoral segmental defect using genetically modified fat}

Key experiments were repeated using gene-activated fat instead of muscle. Cells within discs of fat were readily transduced with Ad.GFP (data not shown). Gene-activated 


\section{CONDYLE}
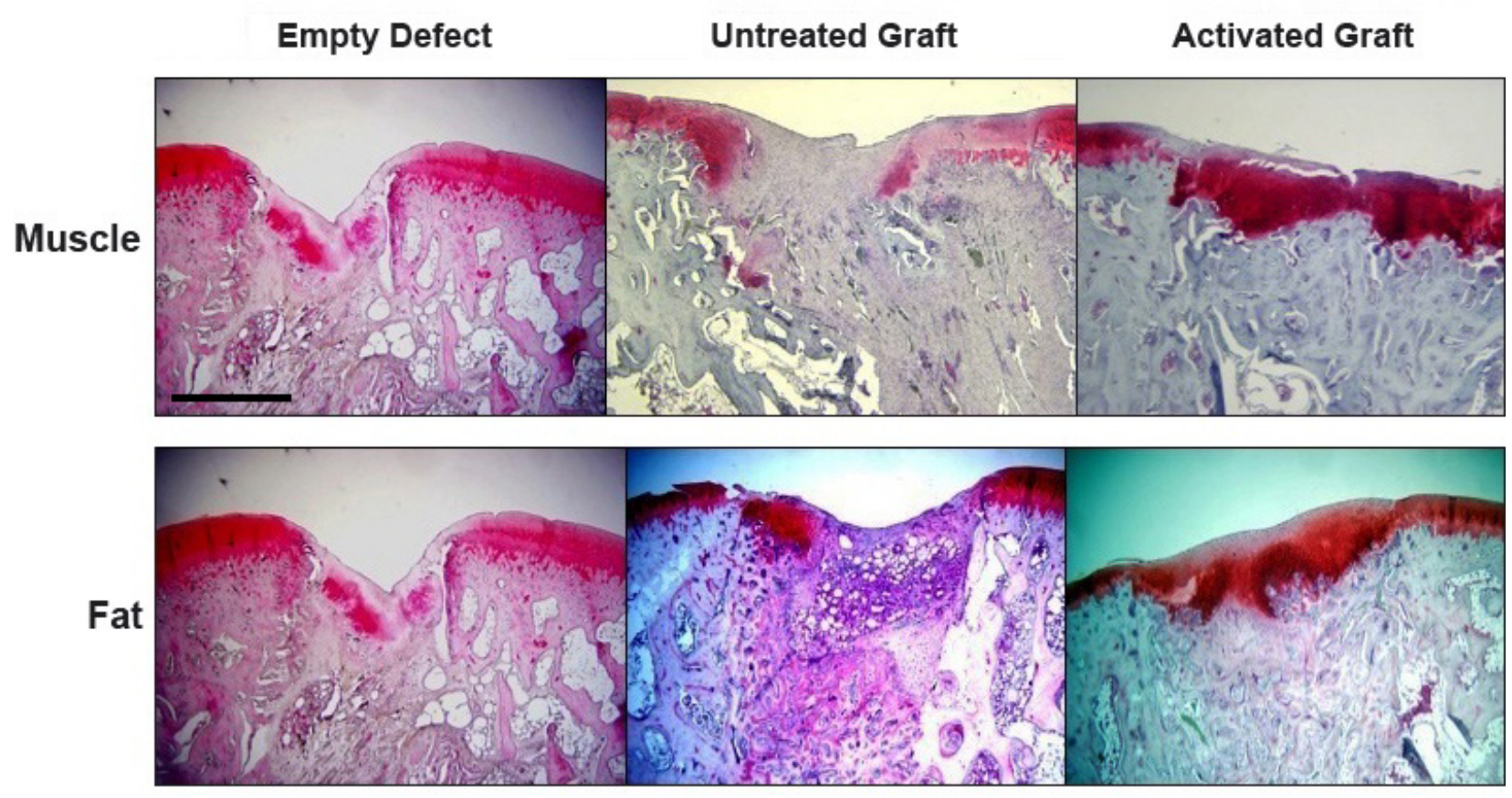

TROCHLEAR GROOVE
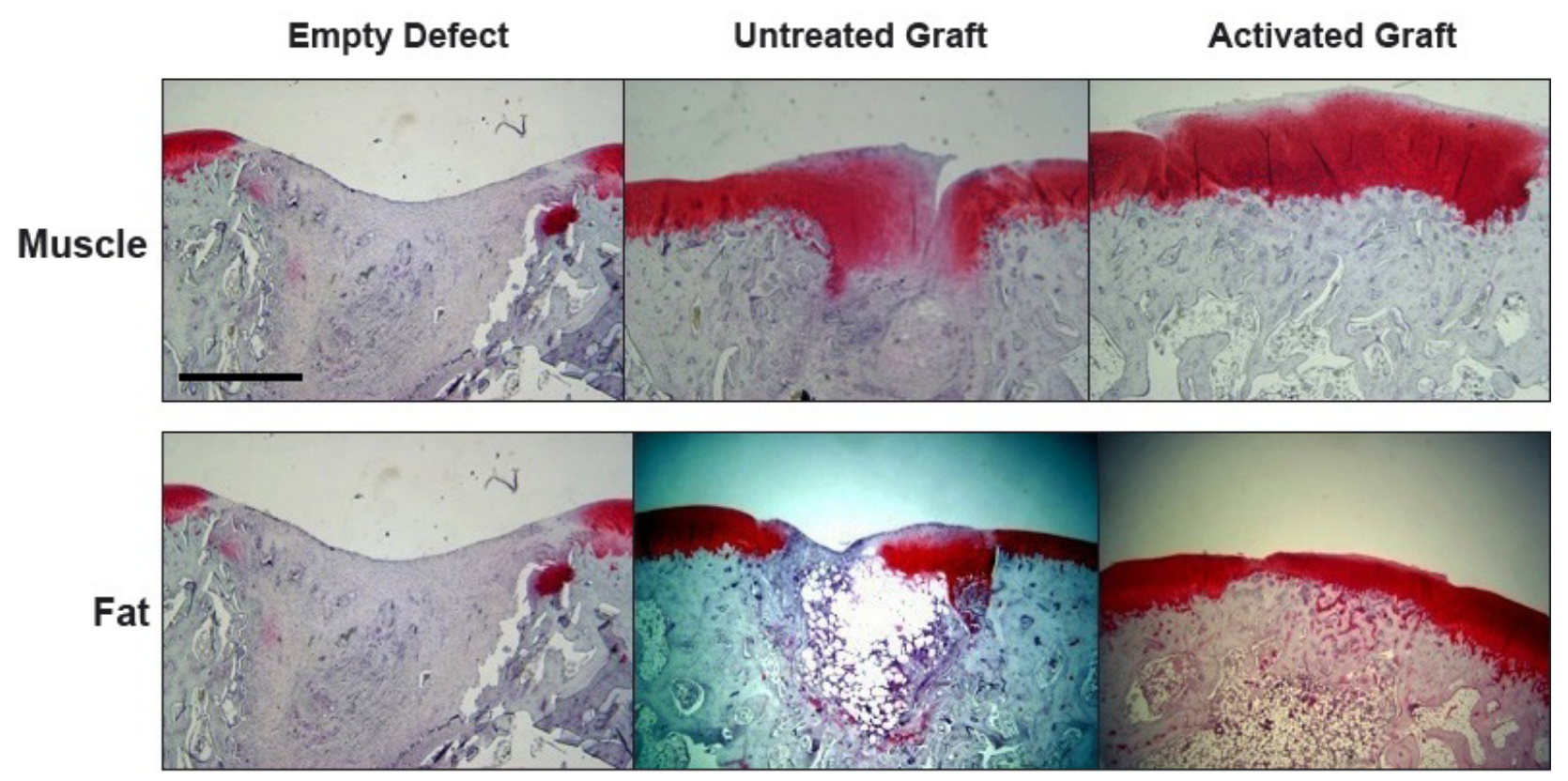

Figure 12. Histological examination of osteochondral defects receiving gene-activated muscle and fat grafts. Sections were stained with safranin O-fast green. Bar $=1 \mathrm{~mm}$

fat was able to heal the femoral defects (Fig. 4) but, based upon radiologic criteria, not as rapidly as gene-activated muscle. Bridging was not observed until 2 weeks. By 8 weeks, the femora healed with gene-activated fat had achieved full mechanical strength and stiffness (Fig. 7). $\mu \mathrm{CT}$ analysis at 8 weeks confirmed the formation of bone throughout the defect with partial restoration of cortices and the presence of trabecular bone (Fig. 5). Histology at
8 weeks showed a similar picture to that seen with geneactivated muscle, with little sign of cartilage or residual fat. Control defects contained only soft tissue (Fig. 8). The data shown in Figs. 4, 5, 6, 7 and 8 were from a single experiment using fat from a single donor. When the experiment was repeated using additional donors, healing was of variable quality (data not shown), which, as discussed later, may reflect heterogeneity of fat from different sources. 


\section{Immune response to adenovirus}

As shown in Fig. 10, the intra-dermal injection of Ad.BMP2 into rats elicited a strong humoral response with the production of antibodies recognizing adenoviral particles. No such responses, however, occurred following the ex vivo implantation of gene-activated fat and muscle and anti-adenovirus levels were no greater than those found in animals receiving unmodified tissue (Fig. 10).

\section{Repair of osteochondral defects in rabbits using genetically modified muscle and fat}

Macroscopic examination suggested that defects treated with either gene-activated muscle or gene-activated fat had healed (Fig. 11). Histology confirmed that untreated defects did not heal, but filled in with amorphous soft tissue. Although some sections contained areas that stained positively with safranin $\mathrm{O}$, there was no evidence of widespread chondrogenesis (Fig. 12). Untreated muscle grafts did not improve healing of the condylar defects but, interestingly, showed improved healing of the trochlear groove defects with significant formation of cartilage staining strongly with safranin-O (Fig. 12). Muscle grafts transduced with Ad.BMP-2, in contrast, considerably improved healing of both the condylar and trochlear groove defects, with the formation of a proteoglycan rich articular surface with sub-chondral bone beneath, and good union with the adjacent, intact cartilage (Fig. 12). Overall, healing was more consistent in the trochlear groove than on the condyles. Fat grafts transduced with Ad.BMP-2 also improved the healing of defects in the condyles and, especially, the trochlear groove where a smooth, proteoglycan rich articular surface was regenerated with good fusion with the adjacent, uninjured cartilage (Fig. 12). Like muscle, unmodified fat demonstrated some ability to regenerate cartilage within the defect.

\section{Discussion}

From the data presented in this paper, we conclude that gene-activated muscle and fat provide promising, novel opportunities for the rapid regeneration of bone, cartilage and perhaps other connective tissues. In the present studies tissue biopsies were transduced with Ad.BMP-2 and implanted in animals some days later, after we had confirmed adequate transgene expression. However, because genetic modification with adenovirus can be accomplished in 2 hours or less, the entire process should be achievable within a single operative procedure thus reducing cost and complexity, as well as sparing the patient a second invasive procedure.

The remarkable potency of this technology is likely to stem from its ability to provide simultaneously the three major requirements of tissue repair: a space filling scaffold; a source of progenitor cells; an inductive stimulus. Healing of large segmental defects in response to rhBMP-2 is known to occur via an endochondral process (Yasko et al., 1992). Because the periosteum is intentionally removed at the time of surgery, there is no immediate source of progenitor cells in this critical sized femoral defect model.
Thus healing is delayed until alternative progenitors arrive from other sources, possibly the bone marrow, surrounding muscle or the periosteum of adjacent, intact bone (Yasko et al., 1992). The direct implantation of tissues that contain progenitor cells thus eliminates what may be the rate limiting process for repair under these circumstances recruitment of progenitors. The absence of periosteum is also likely to account for the lack of an exuberant callus surrounding the defects as they heal.

Histological examination of defects receiving geneactivated muscle suggests a rapid and efficient conversion of muscle into cartilage. Although histology only provides a snap shot, the images indicate efficient ossification occurring at the edges of the cartilage, and by week 4 , cartilage is no longer present. In this respect the hypertrophic cells at the edge of the cartilage resemble the borderline chondrocytes described by Bianco et al. (1998), suggesting that these cells can differentiate into osteoblasts rather than undergoing apoptosis and being replaced by host osteoblasts. Gerstenfeld et al. (2002) have shown that chondrocytes secrete factors with the ability to induce the osteogenic differentiation of mesenchymal progenitor cells, raising the alternative possibility that the graft induces the formation of osteoblasts from host osteoprogenitor cells. To determine whether the newly formed bone was of donor or host origin, we transplanted muscle from male donors into female rats and identified cells bearing Ychromosomes by FISH. The data confirm that at least some of the osteoblasts lining new bone formed within the defect are of donor origin. This finding also reinforces the conclusion that the gene-activated implant is not merely serving as an efficient, local source of BMP-2, but also providing progenitor cells. This is consistent with the observation that the process is only reliably effective when grafting tissue between entirely syngeneic, Fischer rats. The unreliable response of the Sprague-Dawley rats presumably reflects a variable degree of inter-animal MHC mis-match and rejection of the allograft.

It is noteworthy that, although muscle discs transduced with Ad.BMP-2 expressed markers of osteogenesis and deposited a mineralized matrix under in vitro conditions, they appeared first to form cartilage under in vivo conditions. Although the direct differentiation of mesenchymal progenitor cells into osteoblasts might seem a more expeditious route to bone formation in segmental defects, the endochondral route provides certain advantages. Unlike bone formation, chondrogenesis does not require a blood supply. Indeed, during the endochondral process, cartilage secretes soluble angiogenic factors that promote the ingrowth of blood vessels (Petersen et al., 2002). Thus it is not necessary to supply angiogenic factors exogenously, either as proteins or genes. This is a major advantage, especially when considering scaling up from the rat to large animals, such as sheep and, eventually, humans. In the larger animals, critical sized defects in long bones are likely to be hypoxic, a condition that favours chondrogenesis, but impairs direct osteogenesis.

By forming osteoblasts under in vitro conditions but chondrocytes in vivo, the muscle discs demonstrate the importance of the local environment in determining cell 
fate; local cues may be mechanical, as well as chemical and biological. Their importance is most dramatically shown in the experiments where gene-activated muscle and fat grafts were used to repair osteochondral defects in rabbits. After implantation, the top portion of the implant within the cartilage defect formed cartilage, and the lower portion within the sub-chondral bone formed bone, even though the implants were, to the best of our knowledge, homogeneous. The strong influence of the local in vivo environment on differentiation may help to explain why rhBMP-2 is able to heal cartilage lesions in experimental animals without producing hypertrophy and mineralization (Sellers et al., 1997; 2000), whereas in vitro data suggest otherwise (Steinert et al., 2009). Local influences may also explain the spontaneous formation of cartilage by unmodified muscle grafts placed within osteochondral defects and certain femoral defects at late time points.

With both gene activated muscle and fat, healing of defects within the rabbits' trochlear groove was more complete than healing of condylar defects. This probably reflects the harsher mechanical environment of the femoral condyle. Because animals were euthanized after 6 weeks, it is not possible to comment on the durability of the repair. However, these preliminary results are encouraging because there is good integration of the grafts with the surrounding intact cartilage, and reconstitution of the subchondral bone. Moreover, the repair tissue has abundant proteoglycan. The experiments performed in this investigation studied an osteochondral defect, but the technique should also work for partial thickness cartilage defects because it does not rely upon the migration of chondroprogenitor cells from ectopic sites. The technology may also be extended to additional connective tissues, and we have preliminary supporting evidence in the context of tendon healing (Majewski et al., 2008).

Although fat showed promise as a tissue for use in endogenous facilitated repair, its effects were less reliable than those of muscle when healing bone. The reason for this was not thoroughly investigated, but it is our impression that the donor fat was very variable in its consistency, vascularity and cellularity from animal-toanimal, and also between different sites on the same animal. In agreement with this, Tomiyama et al. (2008) have reported cellular differences between the abdominal and sub-cutaneous fat pads in rats. Too few rabbits were studied to permit conclusions to be drawn concerning the reproducibility of the ability of fat to heal osteochondral lesions.

The use of an expedited, ex vivo gene transfer protocol for gene delivery reduces the safety concerns that always burden the clinical use of gene therapy. In particular, because the tissue grafts are transduced with Ad.BMP-2 outside the body, no adenovirus particles are introduced into the patient. Our data suggest that this eliminates the humoral response to the virus, thereby lowering the risk of severe immune reactions of the type that have already caused the death of one subject in a gene therapy trial using adenovirus (Raper et al., 2003). However, cells transduced with first generation adenovirus express viral proteins on their cell surface, which could trigger cell-mediated immunity (Ritter et al., 2002). The significance of this in the present context remains to be determined. In this regard, alternative vectors and non-viral delivery systems could be of interest.

In conclusion, these data demonstrate the remarkable potential of genetically modified, autologous muscle and fat grafts to heal large defects in bone and cartilage. Their potency is likely to reflect the presence of endogenous progenitor cells, the secretion morphogenetic signals by the genetically modified cells and the scaffolding properties of the tissues themselves. Because all manipulations can be carried out within the time frame of a single surgery, the complexity of the procedure is reduced, which should lower costs considerably. Further investigation of the biology that underlies these responses and their evaluation in large animal models should lead to the development of effective human protocols.

\section{Acknowledgements}

This research was funded by NIH grant R01 AR 050243 from NIAMS (to CHE) and the AO Foundation (to MSV and CHE). The authors thank Thomas J. Gill III, MD, Department of Orthopaedic Surgery, Massachusetts General Hospital, for his advice to use Fischer rats.

\section{References}

Baltzer AW, Lattermann C, Whalen JD, Braunstein S, Robbins PD, Evans CH (1999) A gene therapy approach to accelerating bone healing. Evaluation of gene expression in a New Zealand white rabbit model. Knee Surg Sports Traumatol Arthrosc 7: 197-202.

Baltzer AW, Lattermann C, Whalen JD, Ghivizzani S, Wooley P, Krauspe R, Robbins PD, Evans CH (2000a) Potential role of direct adenoviral gene transfer in enhancing fracture repair. Clin Orthop Relat Res 379 (Suppl): S120-125.

Baltzer AW, Lattermann C, Whalen JD, Wooley P, Weiss K, Grimm M, Ghivizzani SC, Robbins PD, Evans $\mathrm{CH}$ (2000b) Genetic enhancement of fracture repair: healing of an experimental segmental defect by adenoviral transfer of the BMP-2 gene. Gene Ther 7: 734-739.

Betz OB, Betz VM, Nazarian A, Egermann M, Gerstenfeld LC, Einhorn TA, Vrahas MS, Bouxsein ML, Evans CH (2007a) Delayed administration of adenoviral BMP-2 vector improves the formation of bone in osseous defects. Gene Ther 14: 1039-1044.

Betz OB, Betz VM, Nazarian A, Pilapil CG, Vrahas MS, Bouxsein ML, Gerstenfeld LC, Einhorn TA, Evans $\mathrm{CH}$ (2006) Direct percutaneous gene delivery to enhance healing of segmental bone defects. J Bone Joint Surg Am 88: $355-365$.

Betz VM, Betz OB, Glatt V, Gerstenfeld LC, Einhorn TA, Bouxsein ML, Vrahas MS, Evans CH (2007b) Healing of segmental bone defects by direct percutaneous gene delivery: effect of vector dose. Hum Gene Ther 18: $907-$ 915. 
Betz VM, Betz OB, Harris MB, Vrahas MS, Evans CH (2008) Bone tissue engineering and repair by gene therapy. Front Biosci 13: 833-841.

Bianco P, Cancedda FD, Riminucci M, Cancedda R (1998) Bone formation via cartilage models: the "borderline" chondrocyte. Matrix Biol 17: 185-192.

Bosch P, Musgrave DS, Lee JY, Cummins J, Shuler T, Ghivizzani TC, Evans T, Robbins TD, Huard (2000) Osteoprogenitor cells within skeletal muscle. J Orthop Res 18: $933-944$

Dragoo JL, Lieberman JR, Lee RS, Deugarte DA, Lee Y, Zuk PA, Hedrick MH, Benhaim P (2005) Tissueengineered bone from BMP-2-transduced stem cells derived from human fat. Plast Reconstr Surg 115: 1665 1673.

Evans CH, Ghivizzani SC, Robbins PD (2004) The 2003 Nicolas Andry Award. Orthopaedic gene therapy. Clin Orthop Relat Res 429: 316-329.

Evans CH, Palmer GD, Pascher A, Porter R, Kwong FN, Gouze E, Gouze JN, Liu F, Steinert A, Betz O, Betz V, Vrahas M, Ghivizzani SC (2007) Facilitated endogenous repair: making tissue engineering simple, practical, and economical. Tissue Eng 13: 1987-1993.

Forsberg JA, Pepek JM, Wagner S, Wilson K, Flint J, Andersen RC, Tadaki D, Gage FA, Stojadinovic A, Elster EA (2009) Heterotopic ossification in high-energy wartime extremity injuries: prevalence and risk factors. J Bone Joint Surg Am 91: 1084-1091.

Gerstenfeld LC, Cruceta J, Shea CM, Sampath K, Barnes GL, Einhorn TA (2002) Chondrocytes provide morphogenic signals that selectively induce osteogenic differentiation of mesenchymal stem cells. J Bone Miner Res 17: 221-230.

Gouze JN, Stoddart MJ, Gouze E, Palmer GD, Ghivizzani SC, Grodzinsky AJ, Evans CH (2004) In vitro gene transfer to chondrocytes and synovial fibroblasts by adenoviral vectors. Methods Mol Med 100: 147-164.

Hardy S, Kitamura M, Harris-Stansil T, Dai Y, Phipps ML (1997) Construction of adenovirus vectors through Cre-lox recombination. J Virol 71: 1842-1849.

Hofstaetter JG, Saad FA, Samuel RE, Wunderlich L, Choi YH, Glimcher MJ (2004) Differential expression of VEGF isoforms and receptors in knee joint menisci under systemic hypoxia. Biochem Biophys Res Commun 324: 667-672.

Hofstaetter JG, Wunderlich L, Samuel RE, Saad FA, Choi YH, Glimcher MJ (2005) Systemic hypoxia alters gene expression levels of structural proteins and growth factors in knee joint cartilage. Biochem Biophys Res Commun 330: 386-394.

Hofstaetter JG, Saad FA, Sunk IG, Bobacz K, Friehs I, Glimcher MJ (2007) Age-dependent expression of VEGF isoforms and receptors in the rabbit anterior cruciate ligament. Biochim Biophys Acta 1770: 997-1002.

Ivkovic A, Pascher A, Hudetz D, Maticic D, Jelic M, Dickinson S, Loparic M, Haspl M, Windhager R, Pecina M (2010) Articular cartilage repair by genetically modified bone marrow aspirate in sheep. Gene Ther, in press.

Kaplan FS, Le Merrer M, Glaser DL, Pignolo RJ, Goldsby RE, Kitterman JA, Groppe J, Shore EM (2008)
Fibrodysplasia ossificans progressiva. Best Pract Res Clin Rheumatol 22: 191-205.

Kuroda R, Usas A, Kubo S, Corsi K, Peng H, Rose T, Cummins J, Fu FH, Huard J (2006) Cartilage repair using bone morphogenetic protein 4 and muscle-derived stem cells. Arthritis Rheum 54: 433-442.

Lieberman JR, Ghivizzani SC, Evans CH (2002) Gene transfer approaches to the healing of bone and cartilage. Mol Ther 6: 141-147.

Majewski M, Betz O, Ochsner PE, Liu F, Porter RM, Evans CH (2008) Ex vivo adenoviral transfer of bone morphogenetic protein 12 (BMP-12) cDNA improves Achilles tendon healing in a rat model. Gene Ther 15: 1139-1146.

Mastrogiacomo M, Derubeis AR, Cancedda R (2005) Bone and cartilage formation by skeletal muscle derived cells. J Cell Physiol 204: 594-603.

Palmer GD, Gouze E, Gouze JN, Betz OB, Evans CH, Ghivizzani SC (2003) Gene transfer to articular chondrocytes with recombinant adenovirus. Methods Mol Biol 215: 235-246.

Pascher A, Palmer GD, Steinert A, Oligino T, Gouze E, Gouze JN, Betz O, Spector M, Robbins PD, Evans CH, Ghivizzani SC (2004) Gene delivery to cartilage defects using coagulated bone marrow aspirate. Gene Ther 11: 133-141.

Petersen W, Tsokos M, Pufe T (2002) Expression of VEGF121 and VEGF165 in hypertrophic chondrocytes of the human growth plate and epiphyseal cartilage. J Anat 201: 153-157.

Pfaffl MW (2001) A new mathematical model for relative quantification in real-time RT-PCR. Nucleic Acids Res 29: e45.

Pfaffl MW, Horgan GW, Dempfle L (2002) Relative expression software tool (REST) for group-wise comparison and statistical analysis of relative expression results in real-time PCR. Nucleic Acids Res 30: e36.

Raper SE, Chirmule N, Lee FS, Wivel NA, Bagg A, Gao GP, Wilson JM, Batshaw ML (2003) Fatal systemic inflammatory response syndrome in a ornithine transcarbamylase deficient patient following adenoviral gene transfer. Mol Genet Metab 80: 148-158.

Ritter T, Lehmann M, Volk HD (2002) Improvements in gene therapy: averting the immune response to adenoviral vectors. BioDrugs 16: 3-10.

Sellers RS, Peluso D, Morris EA (1997) The effect of recombinant human bone morphogenetic protein-2 (rhBMP-2) on the healing of full-thickness defects of articular cartilage. J Bone Joint Surg Am 79: 1452-1463.

Sellers RS, Zhang R, Glasson SS, Kim HD, Peluso D, D'Augusta DA, Beckwith K, Morris EA (2000) Repair of articular cartilage defects one year after treatment with recombinant human bone morphogenetic protein-2 (rhBMP-2). J Bone Joint Surg Am 82: 151-160.

Shore EM, Xu M, Feldman GJ, Fenstermacher DA, Cho TJ, Choi IH, Connor JM, Delai P, Glaser DL, LeMerrer M, Morhart R, Rogers JG, Smith R, Triffitt JT, Urtizberea JA, Zasloff M, Brown MA, Kaplan FS (2006) A recurrent mutation in the BMP type I receptor ACVR1 causes inherited and sporadic fibrodysplasia ossificans progressiva. Nat Genet 38: 525-527. 
Steinert AF, Proffen B, Kunz M, Hendrich C, Ghivizzani SC, Noth U, Rethwilm A, Eulert J, Evans CH (2009) Hypertrophy is induced during the in vitro chondrogenic differentiation of human mesenchymal stem cells by bone morphogenetic protein-2 and bone morphogenetic protein-4 gene transfer. Arthritis Res Ther 11: R148.

Stoltny T, Koczy B, Wawrzynek W, Miszczyk L (2007) Heterotopic ossification in patients after total hip replacement. Ortop Traumatol Rehabil 9: 264-272.

Tomiyama K, Murase N, Stolz DB, Toyokawa H, O’Donnell DR, Smith DM, Dudas JR, Rubin JP, Marra KG (2008) Characterization of transplanted green fluorescent protein+ bone marrow cells into adipose tissue. Stem Cells 26: 330-338.

Wickham MQ, Erickson GR, Gimble JM, Vail TP, Guilak F (2003) Multipotent stromal cells derived from the infrapatellar fat pad of the knee. Clin Orthop Relat Res 412: 196-212.

Yasko AW, Lane JM, Fellinger EJ, Rosen V, Wozney JM, Wang EA (1992) The healing of segmental bone defects, induced by recombinant human bone morphogenetic protein (rhBMP-2). A radiographic, histological, and biomechanical study in rats. J Bone Joint Surg Am 74: 659-670.

\section{Discussion with Reviewers}

Reviewer I: The use of adenoviral vectors remains an issue for some people, what would you see as the most promising alternative gene transfer strategy?

Authors: If adenovirus vectors are not permissible, adenoassociated virus (AAV) is the most promising alternative. It is safe and increasingly used in human gene therapy. Moreover, AAV generates a weaker immune response than adenovirus vectors. The genome of wild-type AAV consists of single stranded DNA, so transgene expression from a recombinant AAV vector used to be limited by the need for second strand DNA synthesis. Recent advances in AAV technology permit the production of AAV vectors with double stranded genomes, which greatly improves expression. Although the AAV genome is small $(\sim 2 \mathrm{~kb}$ packaging for a double stranded vector), cDNAs encoding growth factors such as BMP-2 are small enough to fit comfortably. It is still a challenge to manufacture large amounts of clinical grade vector, but technological improvements continue to be made on this front, too. However, AAV is more expensive to manufacture than adenovirus.

Of the other vectors, pseudotyped lentivirus is very powerful but its approval for human clinical use in nonlethal conditions such as bone healing will be very difficult, because it is an integrating retrovirus with the potential to cause insertional mutagenesis and, hence, cancer. Nonintegrating lentiviruses are being developed. The commonly used oncoretroviral vectors are not useful because they require host cell division for efficient transduction.

Suitable non-viral vectors would be very welcome, because they should be less expensive and raise less safety concerns than viral vectors. However, in our experience, they are too inefficient for present purposes. This is an area of considerable research, so efficient non-viral vectors may become available in the not too distant future. There is considerable interest in using electroporation as one such modality.

Reviewer I: Regarding the different pathways taken by Ad.BMP2 transduced cells in vivo and in vitro, have the authors tried the same procedure in vitro under hypoxic conditions to determine the role of oxygen?

Authors: No, but this would be an interesting project, with the hypothesis that hypoxic conditions favour chondrogenesis. The role of mechanical factors should also be a fruitful area of investigation.

Reviewer II: Concerning the bone defect filled with untreated muscle, the authors showed the presence of cartilage after 12 weeks, while in the AdBMP-2 condition, this was observed after 2 weeks. Is it possible that the non-treatedmuscle may also end up with bone formation, but at later time?

Authors: This is possible, but, unlike the 2-week Ad.BMP2 images, the histology shows no evidence of an endochondral process. It is more likely that the non-treated muscle will end up as an atropic non-union or pseudarthrosis. 